\title{
NATO's Role in Improving Professional Military Education with a Focus on the South Caucasus Countries
}

\section{Khayal Iskandarov ${ }^{1}$ and Piotr Gawliczek ${ }^{2}$}

$1 \quad$ War College of the Armed Forces, Republic of Azerbaijan

2 University of Warmia and Mazury in Olsztyn, Poland

\begin{abstract}
The presented article underlines the priority of education and considers the role of Professional Military Education (PME) in enhancing defense capabilities and preparing the military leaders who are able to make strategic decisions and solve complex problems. It emphasizes a PME as a cornerstone of the military build-up. The authors examine the main characteristics of PME and underscore its importance for increasing the interoperability between the NATO allies and the South Caucasus nations. Taking the broad meaning of interoperability into account, the authors attempted to bring to the fore the critical need for increasing the intellectual interoperability with outside expertise. Further, the authors point out the importance of the Defense Education Enhancement Program (DEEP) as a new system for improving PME and building better-integrated forces in the South Caucasus. At the same time, this article identifies factors that will lead towards the enhancement of the relations amongst the South Caucasus nations themselves. The goal is to consider how the South Caucasus countries can more effectively address the challenges in PME and to formulate suggestions and recommendations. Comparative analysis, synthesis, inductive, and deductive methods have been used to produce conclusive outcomes and recommendations for the countries in the region.
\end{abstract}

Keywords: Professional Military Education, NATO, DEEP, South Caucasus, cooperation, interoperability. 


\section{Introduction}

The world is currently undergoing a much more complicated security environment than it was decades ago. Today's environment is inherently complex, with an increased number of key stakeholders as well as an exponential increase in the connections between these players. With the growth in technology and information exchange, NATO's operational areas are increasingly complex and potentially chaotic. ${ }^{1}$ Thus, as an epicenter of global security, NATO needs to become attuned to the challenges that its member and partner nations encounter. ${ }^{2}$

Education and training are two of the main domains of cooperation between NATO and partner nations. They are what is motivating NATO to shift its attention away from weapons systems to joint, multinational and, interagency education and training of people who can more broadly develop and employ the doctrines, strategies, and policies that integrate all the instruments of power-political, military, economic and informational-to produce leaders better equipped to deal with a range of issues that define the twenty-first-century security environment: "smart power." ${ }^{3}$ It may sound strange, but these initiatives provide NATO with a very important, albeit different role in today's global security landscape. ${ }^{4}$

The nations in the South Caucasus region have been struggling to reach Western standards in every possible field since they gained their independence from USSR. Their armed forces were founded in the period of chaos resulting from the collapse of the Soviet Union when all three countries were suffering from wars. Therefore, defense education occupies one of the first places among these fields, especially regarding the geopolitical landscape of the region. There are different tools and means that can be used to realize this desire to improve their PME. NATO has supported the South Caucasus countries together with other post-Soviet states in reforming their respective security sectors in line with western standards and bringing them closer to the Alliance. It presents the best tools to keep up with the developed or at least developing countries. Of these, the Defense Education Enhancement Program (DEEP) is one of these productive tools to

1 Imre Porkoláb and Ben Zweibelson, "Designing a NATO that Thinks Differently for 21st Century Complex Challenges," Applied Social Sciences DR 1 (2018): 196-212, https://bit.ly/2kJbOpP.

2 Elman Nasirov and Khayal Iskandarov, "The Prospects of Azerbaijan to Enhance Military Interoperability with NATO," Connections: The Quarterly Journal 16, no. 4 (2017): 91-101.

3 James Keagle and Tiffany Petros, "Building Partner Capacity through Education: NATO Engagement with the Partnership for Peace," Connections: The Quarterly Journal 10, no. 1 (2010): 46-63.

4 Aaron Willschick, "In Too 'DEEP.' NATO as an Institutional Educator," NATO Association of Canada, February 22, 2013, https://natoassociation.ca/in-too-deep-nato-asan-institutional-educator/. 
facilitate their integration into Western structures. The goal of this article is to examine how the South Caucasus countries can more effectively address the challenges in PME and to formulate suggestions and recommendations. Comparative analysis, synthesis, inductive, and deductive methods have been used in the study to produce conclusive outcomes and recommendations for the countries in the region.

\section{Professional Military Education: Challenges and Perspectives}

One of the principles that transcend the borders to achieve effective cooperation is changing people and the way they think. First and foremost, it demands investment in education, in changing the way people think. Most importantly, this entails the introduction of new curricula, different faculty and student bodies, and new teaching methodologies based on active learning in order to expand the next generation of leaders' peripheral vision. It is equally important to conduct this transformation in an academic setting in order to adapt to the new security environment. This kind of approach will enrich academic discussion while encouraging the critical thinking that is so essential to addressing today's challenges and highlights the importance of PME. ${ }^{5}$ PME covers a wide range of activities. In one sense, it refers to a plethora of training, continuing education, and other activities designed to provide development to members of the military at various points in their career and to prepare them for the next level of responsibilities. ${ }^{6}$ Thus, the PME strategy is about the balance between training, professional education, and experience. These three factors combine to produce a "theory-practice nexus" that results in the ability to defeat an enemy. If an Army is to be truly adaptable, it needs to maintain a coherent and balanced investment in these factors. While the present balance is acceptable, the changing character of war demands a sustained investment in PME across the Army in order to evolve an increased intellectual edge. ${ }^{7}$ PME itself is not a new phenomenon. For instance, Lorenzo Ruiz attributes the victory of the Prussian Army over the French Army of Napoleon III (at the Battle of Sedan in September 1870) to their institutionalization of three army educational reforms during the 1800s: tiered education, broad curriculum, and historical study. These reforms provided the Prussian leadership with the tools they needed for success on the battlefield and

5 Keagle and Petros, "Building Partner Capacity through Education."

6 Rakesh Sharma, "Professional Military Education and Producing Thought Leaders for the Army," Indian Defence Review, July 17, 2017, www.indiandefencereview.com/ professional-military-education-and-producing-thought-leaders-for-the-army/.

7 Tom McDermott, "Evolving an Intellectual Edge, Professional Military Education for the Australian Army," February 13, 2019, https://cove.army.gov.au/article/evolvingintellectual-edge-professional-military-education-australian-army. 
remain essential components of today's military education systems. ${ }^{8}$ However, over the past generation of international military professional developments in innovation and decision-making, the previously popular mechanistic methods have been challenged by new ways of thinking. ${ }^{9}$ In order to operate more effectively today, military decision-makers need abilities that are related to productive, cognitive, and interactive skills, associated with critical thinking, creativity, problem-solving and interpersonal communication. This means that officers must be taught not what to think but how to think. ${ }^{10}$ Today's military leaders need to be highly adaptable and capable of addressing complex and ambiguous problems. They have to be able to appreciate the complexities of the contemporary operational environment. This development has sparked a variety of lively debates from time to time, which ushered in several publications recommending changes to the PME system. These recommendations varied from drastic curriculum changes to the use of "decision-forcing cases" that promote unconstrained thinking and innovation. The publications raised many valid points, though they failed to address how operational commanders can contribute significantly to the education and training of select officers. Operational commanders from across the joint force should leverage the resources and opportunities provided by PME institutions and proactively invest their time and energy in effectively grooming the next generation of critical thinkers. ${ }^{11}$ Professional Military Education (PME) has always been a critical component in the development of military leaders. It is based upon two key principles: training for certainty so that military personnel gain and master the skills needed for known tasks, and educating for uncertainty so that they have the broad base of knowledge and critical thinking skills needed to handle unanticipated and unpredictable situations. ${ }^{12}$

In order to provide professional development opportunities, professional military education needs a high-quality, effective learning environment. The desired educational outcomes can only be achieved through using teaching methods and instructional activities which promote students' critical thinking. ${ }^{13}$

8 Lorenzo Ruiz, "The Roots of Modern Military Education," RealClear Defense, July 17, 2018, available at https://bit.ly/2IVbTMc.

9 Porkoláb and Zweibelson, "Designing a NATO that Thinks Differently for 21st Century Complex Challenges."

10 Ugis Romanovs, "Professional Military Education. Appreciating Challenges of the Learning Environment," Security and Defence Quarterly 4, no. 5 (2016):58-66, https://doi.org/10.5604/23008741.1191939.

11 Thang Tran, Michael Oliveira, Josh Sider, and Leo Blanken, "Ignorance and Professional Military Education: The Case for Operational Engagement," War on the Rocks, November 7, 2018, https://bit.ly/2yTxx7i.

12 P.K. Mallick, Professional Military Education - An Indian Experience (New Delhi: Krish Printers, 2017), available at https://bit.ly/2mbQn64.

13 Romanovs, "Professional Military Education. Appreciating Challenges of the Learning Environment." 
There are several approaches leading to the improvement of PME. Among other things, David Morgan-Owen ${ }^{14}$ argues for a greater role of civilian academics, giving the audience more freedom in the choice of subjects and methods. Paula Thornhill ${ }^{15}$ and Celestino Perez ${ }^{16}$ respectively, propose reforms that would push PME institutions in a different direction, replacing much academic work with additional opportunities to practice particular military skills. Tammy Schultz and Richard Andres suggest employing mixtures of academic and military elements similar to those currently seen in American war colleges. Bruce Gudmundsson offers "Socratic application," "the Xenophon option," or "reflective professional practice," which guarantees the preparation of officers who are immediately capable of producing first-class staff work and who, at the same time, are fully prepared for the cognitive challenges of a world rich in rapid, repeated, and radical revolutions. ${ }^{17}$

In short, PME is vital to the military's future and, potentially, to the nation as well. This, in its turn, requires future leaders to be able to learn and adapt at all levels. The aim of PME is not to make every leader a professor but instead to make individuals more creative and less risk-averse and to be able to practice the skills of critical thought. Future wars will require leaders who are infinitely adaptable, who use doctrine as a guide and never a rule, and who are able to come up with their own solutions, able to repurpose weapons or technology and invent new ways of doing things quickly. Only those capable of critically analyzing the situation will be able to do this. Furthermore, PME should reach everyone, because we do not know who will be in a critical position at the time when it matters. If it is someone who cannot analyze the situation, think their way through problems, or has a shallow depth of knowledge to draw upon, then the mission could fail and lives could be lost. As David Petraeus stated: "The most important tool that any soldier carries is not his weapon, but his mind." PME sharpens minds and is more likely to result in battlefield success. ${ }^{18}$

14 David Morgan-Owen, "Approaching a Fork in the Road: Professional Education and Military Learning," War on the Rocks, July 25, 2018, https://warontherocks.com/ 2018/07/approaching-a-fork-in-the-road-professional-education-and-militarylearning/.

15 Paula Thornhill, "To Produce Strategists, Focus on Staffing Senior Leaders," War on the Rocks, July 20, 2018, https://warontherocks.com/2018/07/to-produce-strategistsfocus-on-staffing-senior-leaders/.

16 Celestino Perez, "What Military Education Forgets: Strategy is Performance," War on the Rocks, September 7, 2018, https://warontherocks.com/2018/09/what-militaryeducation-forgets-strategy-is-performance/.

17 Bruce Gudmundsson, "A Fourth Way in Professional Military Education," War on the Rocks, October 2, 2018, https://warontherocks.com/2018/10/a-fourth-way-inprofessional-military-education/.

18 Freddie, “Does Professional Military Education Matter?" Wavell Room, May 16, 2019, https://wavellroom.com/2019/05/16/does-pme-matter/. 
At the end of 2015, the King's CMEO put together its first-ever PME Working Group at the Joint Services Command and Staff College (Shrivenham, UK). The event was attended by 35 military education practitioners from nations including Canada, Egypt, Georgia, Japan, Kuwait, Nigeria, Norway, Pakistan, Qatar, Singapore, and the UK. As part of the workshop, evaluation forms were handed out to attendees asking them to provide their insight on the future strategic goals for PME. Due to the mix of internationals who were present at the working group, attendees were asked to place seven "strategic challenges" into categories of importance (Table 1.1).

Table 1. Evaluation form (distribution of responses in percentage points).

\begin{tabular}{|c|c|c|c|c|c|}
\hline 1 & 2 & 3 & 4 & 5 & Strategic challenges \\
\hline 50 & 17 & 17 & 17 & 0 & $\begin{array}{l}\text { Democratizing education, i.e., better professional } \\
\text { development for all officers, not just the top } 20 \%\end{array}$ \\
\hline 17 & 17 & 33 & 33 & 0 & $\begin{array}{l}\text { Phasing out the "three-tier" education system, } \\
\text { into a continuous "through-life" learning process }\end{array}$ \\
\hline 50 & 50 & 0 & 0 & 0 & $\begin{array}{l}\text { Developing strategic thinking competencies for } \\
\text { senior officers and future leaders }\end{array}$ \\
\hline 25 & 75 & 0 & 0 & 0 & $\begin{array}{l}\text { Developing strategic awareness competencies for } \\
\text { junior officers (to deal with unconventional war- } \\
\text { fare, including the perils of real-time media cov- } \\
\text { erage) }\end{array}$ \\
\hline 0 & 0 & 60 & 20 & 20 & $\begin{array}{l}\text { Advancing the effectiveness of alumni networks } \\
\text { for knowledge sharing and defense diplomacy }\end{array}$ \\
\hline 0 & 33 & 50 & 17 & 0 & $\begin{array}{l}\text { Increasing cross-cultural capabilities for officers } \\
\text { (for peacekeeping, diplomacy, coalition opera- } \\
\text { tions, etc.) }\end{array}$ \\
\hline 40 & 60 & 0 & 0 & 0 & $\begin{array}{l}\text { Enhancing coalition and partner capacity to ena- } \\
\text { ble joint strategic planning and joint-by-proxy op- } \\
\text { erations }\end{array}$ \\
\hline
\end{tabular}

The categories used were: 1 . Top priority; 2. Very important; 3. Important (but not urgent); 4. Useful (but not important); and 5. Counter-productive. According to the results, $50 \%$ of attendees chose "Democratizing education" and "Developing strategic thinking competencies for senior officers and future leaders" as a top priority. Interestingly, $40 \%$ of attendees pointed to enhancing coalition and partner capacity as a "top priority" in order to enable joint strategic planning and joint-by-proxy operations (for $60 \%$ of attendees, it was "very important"). The bottom line is, even though there are variations between the PME requirements of different nations, for educators across the world, there exists an increasing emphasis on improving strategic competencies at all levels of officer education, a joint approach between forces, blended learning techniques, 
and professional development for the $80 \%$ of officers who fall outside of the traditional advanced command and staff course system. ${ }^{19}$

\section{NATO's Role in Improving PME in the South Caucasus Countries}

In order to ensure an effective educational process, the focus should be on the implementation and development of effective management mechanisms, reasonable distribution of resources, constant development of intellectual resources, refinement of military educational programs, improvement of educational assets, and implementation and development of modern methods and technologies of learning and evaluation. It will be essential to pay special attention to the continuous succession of scientific attitudes to the development of educational programs in the military educational institutions, which involves analysis, planning (design), development, performance, and evaluation. ${ }^{20}$ The challenge is how to achieve this. A single nation on its own cannot achieve it all. There is a need for practical support, which can be provided through different resources, and NATO would seem to have the best means available. Education is a key agent of transformation and NATO is using it to support institutional reform in the South Caucasus countries. According to international standards, in the process of continuously updating training, education, and evaluation methods, it is essential to consider the experiences of appropriate military educational programs and institutions in NATO and its partner states. International collaboration, focused on the support of current capabilities, can definitely improve the quality of education in the military educational institutions. This leads to the compatibility of armed forces with NATO and its success in joint operations. ${ }^{21}$

The Alliance's education and training programs, which initially focused on increasing interoperability between NATO and partner forces, have been expanded. Currently they provide also a means by which Allies and partners can collaborate on how to build, develop and reform educational institutions in the security, defense, and military domains. ${ }^{22}$ As Ronald Schmied, the evaluation director of Austrian Joint Forces Command, mentioned: "For Austria, it is im-

19 Duraid Jalili, "Future Strategic Priorities, for Professional Military, Education: A Practitioner Perspective," Defence-in-Depth, April 18, 2016, https://defenceindepth.co/ 2016/04/18/future-strategic-priorities-for-professional-military-education-apractitioner-perspective/.

20 Ministry of Defense of Georgia, "Vision of the Training and Military Education Command," n.d., https://mod.gov.ge/en/page/57/vision-of-the-training-and-militaryeducation-command.

21 Ministry of Defense of Georgia, "Vision of the Training and Military Education Command."

22 Joshua Kucera, "Uzbekistan Asks NATO for Military Education Help," Eurasianet, February 5, 2013, https://eurasianet.org/uzbekistan-asks-nato-for-military-educationhelp. 
portant to be in line with international standards due to the fact Austria has a huge contribution to missions not only for NATO but also for the European Union and the United Nations. NATO provides a tool to check those standards." 23

The principal feature of NATO education and training Partnership Tools is that it provides the perfect opportunity for the South Caucasus countries to specialize in a particular area of expertise. Specialization further enhances other factors, which can be beneficial for regional cooperation. These include ${ }^{24}$ :

- knowledge exchange, enabled by the exchange of students and instructors;

- $\quad$ bigger training audiences through the deployment of Mobile Training Teams and the exchange of instructors;

- $\quad$ strengthened personal links among the personnel in the region;

- discussion platforms provided by organizing different networking events and meetings.

NATO education and training has greatly expanded from what it once was. Historically, NATO education was focused on ensuring military forces from member countries could work together effectively in missions and operations. Today, NATO education and training functions have drastically expanded to the point that now the Alliance has a network of training schools and institutions, conducts regular exercises, and runs training missions as far away as Afghanistan and Africa. ${ }^{25}$ NATO shares its expertise with the South Caucasus countries in order to assist them with defense education and training reform through a set of mechanisms. By joining different NATO initiatives, these countries can open up the opportunity to exchange insights and experience in areas of common interest, gain access to the advice and support of NATO experts, as well as engaging in various NATO events and activities. Partnership education and training mechanisms are predominantly designed as bilateral tools - focused on enhancing cooperation and interoperability between the Alliance and the partner. ${ }^{26}$ Through this aspect of cooperation, officers and troops of the South Caucasus region can become familiar with NATO standards, language and procedures and get to know Allied

23 "Austria: NATO Picks off Europe's Remaining Neutrals," June 5, 2013, https://rickrozoff.wordpress.com/2013/06/05/austria-nato-picks-off-europesremaining-neutrals/.

24 Marija Ignjatijevic, How Can NATO Contribute to Regional Cooperation in the Field of Training and Education? (Belgrade Centre for Security Policy, 2019), https://bezbed nost.org/en/publication/how-can-nato-contribute-to-regional-cooperation-in-thefield-of-training-and-education/.

25 Willschick, "In Too 'DEEP.' NATO as an Institutional Educator."

26 Ignjatijevic, How Can NATO Contribute to Regional Cooperation. 
and partner officers in preparation for future cooperation in theatre. ${ }^{27} \mathrm{~A}$ major component of NATO teaching is the broad range of courses and seminars offered on both strategic and operational issues. Although the courses differ, they tend to focus on the knowledge and skills required by those who will occupy senior or specialized positions within the structure of the Alliance, or who hold NATO related posts in their home countries. ${ }^{28}$

The South Caucasus countries have made, and continue to make, significant contributions to the Alliance's operations and missions. A number of tools have been developed to assist them in enhancing their own defense capacities and defense institutions, ensuring that their forces are able to provide for their own security, are capable of participating in NATO-led operations, and are interoperable with Alliance forces. ${ }^{29}$

Changing how people think, how they approach problems and analyze (evaluate) courses of action, and how they implement their assignments will pose considerable challenges to all armed forces for the foreseeable future. The South Caucasus countries, like other Partnership for Peace partners, also recognize the need for education and training to address a wide range of security challenges. Therefore, they have raised education and training transformation to one of the highest priorities in their agreed NATO IPAPs. ${ }^{30}$ However, PME in these countries lags behind that in the Western armies. Education and training transformation is a high-priority mission that will need to be sustained for decades in order to contribute to more rational decisions, better leadership, and, ultimately, a long-lasting peace in the region. ${ }^{31}$ These countries are fully aware of this, and, for now, NATO offers a window of opportunity. At the same time, the NATO DEEP ADL Portal is available, and it creates a compendium of expertise in the use and implementation of new technologies in defense education and training ${ }^{32}$ that is of importance when considering developments within the security environment. ${ }^{33}$

27 NATO, “The Secretary General's Annual Report 2015," January 7, 2016, available at www.nato.int/nato_static_fl2014/assets/pdf/pdf_2016_01/20160128_SG_AnnualRe port_2015_en.pdf.

28 Willschick, "In Too 'DEEP.' NATO as an Institutional Educator."

29 NATO, "The Secretary General's Annual Report 2015."

30 Keagle and Petros, "Building Partner Capacity through Education."

31 Keagle and Petros, "Building Partner Capacity through Education."

32 Piotr Gawliczek, "Innovative ICT Solutions and/within/for Changing Security Environment. Case Study - NATO DEEP ADL Portal and Social Media," Journal of Scientific Papers. Social Development Security 9, no. 4 (2019): 111-119, https://doi.org/10.33 445/sds.2019.9.4.8.

33 Piotr Gawliczek, "Security Environment Perceived from Innovative Information/ Communications Technology and Social Media Perspective. Towards System Solutions," in Security and Russian Threats, ed. Mirosław Banasik, Piotr Gawliczek, and Agnieszka Rogozińska (Kielce, Poland: Jan Kochanowski University of Kielce, 2019), pp. 251-264. 


\section{Conclusions}

The primary challenge for the South Caucasus is definitely security and stability. However, there is a conflict of interests among the external actors regarding the region and amongst the South Caucasus countries themselves. Georgia is convinced that NATO's involvement is important, whereas Armenia, as a member of CSTO, excludes it. Azerbaijan is more prudent, trying to strike the right balance between various external actors. However, all three of them are concerned with the region's stability, and all countries are eager to improve their military capabilities.

Professional military education is a cornerstone of military enhancement. Therefore, these three nations should have a PME program that enables them to have the right contingent with the right education. Considering that all three nations lag behind developed countries in their defense education, there are some possible tools open to all of them to improve their capability. NATO is a dynamic organization, trying to keep abreast of modern requirements. For now, NATO provides the best tools for improving defense education. Therefore, all three countries in the South Caucasus have reasons for cooperating with NATO, even though they do not, necessarily, implement NATO-initiated programs with the same intensity.

\section{Disclaimer}

The views expressed are solely those of the authors and do not represent official views of the PfP Consortium of Defense Academies and Security Studies Institutes, participating organizations, or the Consortium's editors.

\section{Acknowledgment}

Connections: The Quarterly Journal, Vol. 18, 2019 is supported by the United States government.

\section{About the Authors}

Khayal Iskandarov - see p. 34 in this issue, https://doi.org/10.11610/Connec tions.18.3-4.01

Piotr Gawliczek - see p. 34 in this issue, https://doi.org/10.11610/Connec tions.18.3-4.01 